\title{
Teachers' Questioning Strategies in Indonesian Language Learning
}

\author{
Kristianus Wilpas Bata* \\ Indonesian Language and Literature Education of Graduate \\ School \\ Universitas Negeri Yogyakarta \\ Yogyakarta, Indonesia \\ kristianusbata@yahoo.co.id
}

\author{
Zamzani \\ Indonesian Language and Literature Education of Graduate \\ School \\ Universitas Negeri Yogyakarta \\ Yogyakarta, Indonesia \\ zamzani@uny.ac.id
}

\begin{abstract}
This work presents questioning strategies used by teachers, the cognitive realm of teacher questions on the use of questioning strategies in the Indonesian learning process, and the application of teacher questioning strategies in the structure of Indonesian language learning. Data collection techniques used are listen, record, and record. The instrument used in this study was the human instrument. The results of the study can be detailed as follows. First, the questioning strategy used by the teacher includes: 1) the use of the redirection question strategy by the teacher during the learning process, marked by questions that make students active as a whole, 2) the use of prompting question strategies by the teacher during the learning process, marked by giving questions that lead students to answer correctly, and 3) the use of probing question strategies by the teacher during the learning process, marked by questions that dig deeper information. Second, the cognitive realm of teacher questions on the use of questioning strategies in the Indonesian learning process includes the following aspects: memory, understanding, application, analysis, evaluating, and creating. Third, the teacher's questioning strategy in the structure of Indonesian language learning includes the questions at the beginning, in the middle, and at the end of learning.
\end{abstract}

Keywords-asking, questioning strategies, cognitive domains of questions, learning structures

\section{INTRODUCTION}

In the process of learning Indonesian in high school, students encounter a particular problem. The problem is that the teacher gives more memory memorizing questions and puts more emphasis on mastering the material as much as possible so that the learning atmosphere is rigid. This results in the learning process centering in one direction only, and does not provide opportunities for students to learn more actively by developing thinking skills. The use of questioning strategies in the classroom aims to help students learn content and to teach them to think more critically and analytically. Teaching and learning activities (learning and teaching) language must be well realized by the instructor (teacher) in the context of developing the skills and thinking abilities of students as learning subjects (Zamzani, 2014: 9). One way to develop students' thinking skills and abilities in the learning process is to ask questions. Teachers are required to be able to give questions in the learning process that can develop students' thinking skills and abilities so that learning goals can be achieved. In the learning process, questions that develop students' thinking skills and abilities refer to the cognitive process dimensions of Bloom's Taxonomy. Giving questions aims to make the lesson clear, so that it is able to develop students' thinking skills and abilities (Anderson \& Krathwohl, 2001).

Another problem occurs when students cannot answer questions because of the way the teacher gives questions. When asking questions, the teacher's position tends to be powerful, while the student's position is powerless. Students are not empowered to be themselves and the teacher does not stimulate students to be involved in classroom activities. This learning process has not yet encouraged students to develop thinking skills. Brown, cited in Hasibuan et al. (1988, p. 19), argues that asking questions creates knowledge in students. Asking is very closely related to thinking, as expressed by John Dewey, "Thinking itself is question". Sadiman, as cited in Uno (2006, p. 170) described asking as a verbal greeting and a response to someone known. Asking questions is one of the social competencies that children bring to school (Moreillon, 2007, p. 58). The purpose of asking questions is not merely to obtain information, but also to improve students' thinking abilities (Hasibuan \& Moedjiono, 2012, p. 62). Munandar, as cited in Mulyana (2012) said that asking can be interpreted as a desire to find information that is not yet known. Asking is one of the strategies to attract the attention of the listeners, especially regarding important matters that require attention and need to be questioned (Majid, 2013, 235).

Other problems also arise when the teacher uses the questioning strategy. After giving questions, typically the teacher only gives one second to ask students to answer questions (Sadker, et al., 2011; Wilen, 1987). This results in students not having time to think to answer teachers' questions. In addition, the teacher only gives questions to students who have higher ability without giving questions to other students. This learning process prevents other students from having the opportunity to think and answer the teacher's questions. When students incorrectly answer teachers' questions, teachers generally move to other students. This certainly makes students discouraged and psychologically feel displaced from the discussion (Jacobsen, Eggen \& Kauchak, 2009).

It can be understood that questions have an important role in learning. Questions as a means to increase the effectiveness of learning. As stated by Hunkins, cited in Wilen (1987, p. 154) 'questions can facilitate individual thinking, enabling active participation in learning'. So, the use of questioning strategies by teachers in a learning process 
is very important because it can provide various benefits. The use of questioning strategies can help learning be effective, both in quality and quantity. In quality, questions can broaden student understanding and improve the quality of answers given. In terms of quantity, active involvement of students in learning can be increased by involving students. Therefore, questioning strategy is one of the main things in learning. If used effectively, it will enable teachers to achieve learning goals delivered well. However, there are gaps or discrepancies in the reality of learning activities with ideal conditions based on theory. The discrepancy raises various problems caused by the strategies used by the teacher in giving questions. Although it is a small part of learning, it has a big impact. Teachers often ignore the questioning strategy in the teaching and learning process. This will certainly harm the teacher and students. This is in accordance with what Feldman stated that "many teachers feel inadequately prepared in this critical component of effective teaching. Teacher education and induction programs sometimes gloss over questioning strategies. This is a service to both teachers and their students." Therefore, in the learning process teachers must pay attention to the strategy of delivering a) redirection questions, b) prompting questions, and c) probing questions (Jacobsen, Eggen \& Kauchak, 2009, pp. 179-186).

In applying the questioning strategy, teachers need to pay attention to the learning structure which includes beginning, middle, and koda (Tarigan (1987). The questioning strategy in structuring the teaching and learning process refers to the ranking scale of conversations in the teaching and learning process by extending lessons, transactions, exchanges, moves, and actions (Sinclair \& Coulthard, 1975). Ranking scale in the learning process is carried out so that the learning process runs in accordance with the learning objectives, learning materials, and student circumstances such as abilities, interests and environment. This ranking scale is able to encourage students' thinking ability and motivation to learn (Edmondson, 1989).

Based on the description above, the use of teacher questioning strategies in the Indonesian teaching and learning process is very much needed. This is the background why this study aimed to examine the use of teachers' questioning strategies in the Indonesian high school teaching and learning process.

\section{METHODOLOGY}

This study was a qualitative research since it intended to understand phenomena about something experienced by the research participants holistically and descriptively in their natural context (Moleong, 2004). The study involved three Indonesian language teachers of high school and investigated the use of questioning strategies by the teacher participants during the teaching and learning process. The focuses of the investigation were the teachers' questioning strategy, the cognitive realm of the teachers' questions on the use of questioning strategies in the Indonesian teaching and learning process, and the application of the teachers' questioning strategy in the Indonesian learning structure. The data collection techniques used included referring, recording, and recording (Sudaryanto, 2001) The instrument used in this study was the human instrument (Ghony \& Almanshur, (2012). The collected data were analyzed with descriptive qualitative in the form of words or images, not numbers as in quantitative research (Arikunto, 2002). The validity of the data was done by extending the time of observation during the study, seriousness and perseverance in conducting research, triangulation of data sources, and discussions with colleagues

\section{DISCUSSION}

A. Results

- Used by teachers in the Indonesian learning process

\begin{tabular}{|c|c|c|c|c|c|c|c|}
\hline No. & Questioning & \multicolumn{6}{|c|}{ Teacher } \\
\cline { 3 - 8 } & Strategies & & GR I & \multicolumn{2}{|c|}{ GR II } & \multicolumn{2}{|c|}{ GR III } \\
\cline { 3 - 8 } & & Y & N & Y & N & Y & N \\
\hline 1. & Redirection & $\checkmark$ & & $\checkmark$ & & $\checkmark$ & \\
\hline 2. & Prompting & $\checkmark$ & & $\checkmark$ & & $\checkmark$ & \\
\hline 3. & Probing & $\checkmark$ & & $\checkmark$ & & $\checkmark$ & \\
\hline
\end{tabular}

Note:

$\mathrm{Y}:$ Yes $\mathrm{N}$ : None

Cognitive Domains of Teacher Questions on the Use of Questioning Strategies in Indonesian Language

\begin{tabular}{|c|c|c|c|c|c|c|c|c|c|c|c|}
\hline \multirow{3}{*}{$\begin{array}{l}\mathrm{N} \\
\mathrm{o}\end{array}$} & \multirow{3}{*}{$\begin{array}{l}\text { Questioni } \\
\text { ng } \\
\text { Strategie } \\
\text { s }\end{array}$} & \multirow{3}{*}{$\begin{array}{c}\text { Cognitive } \\
\text { Aspects }\end{array}$} & \multicolumn{9}{|c|}{ Teacher } \\
\hline & & & \multicolumn{3}{|c|}{ GR I } & \multicolumn{3}{|c|}{ GR II } & \multicolumn{3}{|c|}{ GR III } \\
\hline & & & $\mathbf{Y}$ & $\mathbf{S}$ & $\mathbf{N}$ & $\mathbf{Y}$ & $\mathbf{S}$ & $\mathbf{N}$ & $\mathbf{Y}$ & $\mathbf{S}$ & $\mathbf{N}$ \\
\hline \multirow[t]{6}{*}{1.} & \multirow{6}{*}{$\begin{array}{c}\text { Redirectio } \\
n\end{array}$} & Remember & $\sqrt{ }$ & & & $\checkmark$ & & & $\checkmark$ & & \\
\hline & & Understand & $\checkmark$ & & & $\checkmark$ & & & $\checkmark$ & & \\
\hline & & Apply & $\checkmark$ & & & & & $\checkmark$ & & $\checkmark$ & \\
\hline & & Analyze & & & $\checkmark$ & & & $\checkmark$ & & & $\checkmark$ \\
\hline & & Evaluate & & & $\checkmark$ & & & $\checkmark$ & & & $\checkmark$ \\
\hline & & Create & & & $\sqrt{2}$ & & & $\checkmark$ & & & $\checkmark$ \\
\hline \multirow[t]{6}{*}{2.} & \multirow{6}{*}{ Prompting } & Remember & $\sqrt{ }$ & & & & $\sqrt{ }$ & & $\checkmark$ & & \\
\hline & & Understand & $\checkmark$ & & & & $\checkmark$ & & $\checkmark$ & & \\
\hline & & Apply & $\sqrt{ }$ & & & & $\checkmark$ & & & $\checkmark$ & \\
\hline & & Analyze & & & $\sqrt{ }$ & & & $\sqrt{ }$ & & & $\checkmark$ \\
\hline & & Evaluate & & & $\checkmark$ & & & $\sqrt{ }$ & & & $\checkmark$ \\
\hline & & Create & & & $\checkmark$ & & & $\checkmark$ & & & $\checkmark$ \\
\hline \multirow[t]{6}{*}{3.} & \multirow[t]{6}{*}{ Probing } & Remember & $\sqrt{ }$ & & & $\checkmark$ & & & $\checkmark$ & & \\
\hline & & Understand & $\checkmark$ & & & $\checkmark$ & & & $\checkmark$ & & \\
\hline & & Apply & $\checkmark$ & & & & & $\sqrt{ }$ & & & $\checkmark$ \\
\hline & & Analyze & & & $\checkmark$ & & & $\checkmark$ & & & $\checkmark$ \\
\hline & & Evaluate & & & $\sqrt{ }$ & & & $\sqrt{ }$ & & & $\checkmark$ \\
\hline & & Create & & & $\checkmark$ & & & $\checkmark$ & & & $\sqrt{ }$ \\
\hline
\end{tabular}

Note:

$\mathrm{Y}:$ Yes $\quad \mathrm{S}:$ Sometimes $\quad \mathrm{N}$ : None

- Application of Teachers' Questioning Strategies in Indonesian Language Learning Structure

\begin{tabular}{|c|c|c|c|c|c|}
\hline No & \multirow{2}{*}{ Teacher } & $\begin{array}{c}\text { Questioning } \\
\text { Strategies }\end{array}$ & \multicolumn{4}{|c|}{$\begin{array}{c}\text { Learning } \\
\text { Structure }\end{array}$} \\
\cline { 3 - 6 } & & & B & M & K \\
\hline \multirow{2}{*}{1.} & \multirow{2}{*}{ GR I } & Redirection & $\checkmark$ & $\checkmark$ & $\checkmark$ \\
\cline { 3 - 6 } & & Prompting & $\checkmark$ & $\checkmark$ & $\checkmark$ \\
\hline & & Probing & $\checkmark$ & $\checkmark$ & $\checkmark$ \\
\hline 2. & \multirow{2}{*}{ GR II } & Redirection & $\checkmark$ & $\checkmark$ & $\checkmark$ \\
\cline { 3 - 6 } & & Prompting & $\checkmark$ & $\checkmark$ & $\checkmark$ \\
\hline
\end{tabular}




\begin{tabular}{|c|c|c|c|c|c|}
\hline & & Probing & $\checkmark$ & $\checkmark$ & $\checkmark$ \\
\hline 3. & \multirow{3}{*}{ GR III } & Redirection & $\checkmark$ & $\checkmark$ & $\checkmark$ \\
\cline { 3 - 6 } & & Prompting & $\checkmark$ & $\checkmark$ & $\checkmark$ \\
\cline { 3 - 6 } & & Probing & $\checkmark$ & $\checkmark$ & $\checkmark$ \\
\hline
\end{tabular}

Note:

B : Beginning $\quad \mathrm{M}$ : Middle $\mathrm{K}$ : Koda

\section{B. Discussion}

The discussion section highlights various teachers' questioning strategies, the cognitive realm of teacher questions, and the structure of teacher questions, as well as the form of questions in the process of teaching and learning in Indonesian high schools.

- Questioning Strategies Used by Teachers to Give Questions to Students in the Indonesian Language Learning Process

\section{a. Redirection Questions}

Based on the results of observations, in teaching and learning interactions, there is a conversation between the teacher and students. Often the interaction takes place in the form of asking questions to students or to several students. The teacher addressed a number of questions in which the use of the redirection questions strategy was applied. The use of redirection questions strategy aims to create more active and comprehensive teaching and learning conditions. The following data showed the teachers' use of the redirection questions strategy when asking questions to their students in the process of learning Indonesian in class.

Teacher : Good morning. Today we will discuss facts and opinions. Anyone knows what facts are? Try the last one, is that a fact?

Student : Something really happened (CL.I/GR.I /001)

Teacher : Okay, Any other opinions?

Student : In line with reality, ma'am.

Student : Can be proven true. (CL.I / GR.I / 002)

Teacher : Well then, what is according to the truth?

Student : not containing someone's opinion

Student : Does not match reality. (CL.I / GR.I /

003)

In the above data, the teacher asked questions to students, then students answered the teachers' questions. However, the teacher felt that from these questions different answers can arise from other students. The teacher then asked other students who can give different answers to the same questions as in the question data above. The data above showed that the teacher applied the strategy redirection questions when asking questions in the teaching and learning process. This strategy is used when the teacher intends to get different answers from each student for one question.

\section{b. Prompting Questions}

In the observation or observation of the teaching and learning interaction process in class, there is the use of prompting questions by the teacher in asking questions to students. The use of this strategy can create a studentcentered learning environment. For example, when the teacher advanced questions about saga and students did not know about saga, he presented other questions that stimulated students to answer these questions. The teacher's questions were the given short story. Questions about the short story that led students to answer the first question was saga. This encouraged students to find answers to the teacher's questions. The following is a description of the use of prompting questions by the teacher during the teaching and learning process in class.

Teacher : Good morning. Today we will study material about saga. Has anyone ever heard of the word Tell?

Student : Ever. (CL.III / GR.I / 131)

Teacher : If so, what is Tell?

Student : (No one answers)

Teacher : Wow, I heard that I've heard, let's answer, does anyone know about saga?

Student : Don't know ma'am. (CL.VIII/GR.I /132)

Teacher : Good, have heard but don't know. Okay, now I'm trying to ask about a short story, still remember? What is meant by a short story?

Student : Short stories are a new form of prose.

Student : Using everyday language ...

Student : Using a single path. (CL.VIII/GR.I/133)

Teacher : That's right. What is the short story usually about?

Student : Life experience of the author or based on the author's thoughts. (CL.VIII / GR.I / 134)

Teacher : (The teacher nods) That's right. Now, if we already know that short stories are a new form of prose written by the author based on life experience, then what is saga?

Student : Story is an old literary work or old prose. (CL.VIII / GR.I / 135)

Teacher : Good, saga is one of the old prose ... Anybody want to add?

Student : Imaginative or imaginary or imaginary.

Student : Tells the life of a palace or kingdom.

Teacher : What you answered is true. Story is a historical story or life history, in which there are many things that do not make sense and are full of miracles. This saga tells the life of the royal family or the nobility, famous people, saints around the palace with all the magic, strangeness and miracles of the main character. (CL.VIII / GR.I / 136)

The teacher gave questions about short stories to guide students to be able to answer and try to think. After the teacher asked questions about the short story and students were able to answer them, the teacher had to ask about the saga again. As shown in the above transcript, the researcher found that the questions given by the teacher initially were not able to be answered by students. Seeing this, the teacher then asked guiding questions or other questions that were almost related to the original questions. This method can also be used when the answers given by students are wrong. Guiding questions given by the teacher in the data above are very helpful for students to answer the questions correctly. This shows that the use of prompting strategies involves cues signs or hints that can help students answer the teacher's 
questions correctly (Jacobsen, Eggen \& Kauchak, 2009, p. 181).

\section{c. Probing Questions}

The observations obtained by the author during the research of the Indonesian learning process indicate the use of the probing questions strategy by the teacher in giving questions to students. Questions using the probing questions strategy are said to take place if the teacher asks questions that can provide opportunities for students to express creatively while still increasing student participation in the learning process. This strategy is commonly used by teachers to deal with wrong answers in an informative and human way. Below is the data obtained by the researcher.

Teacher : Do you think there is value in the saga?

Student : There is Ma'am.

Teacher : Determine what values are contained in the saga and include with supporting sentences?

Student : Social Value. The supporting sentence "Because of pity with the Poor, there are people who sympathize with him who give mango, rice, clothes, and other fruits". (CL.XII / GR.I / 163)

Teacher : Alright, now I want to ask on what basis are you or the authentic evidence so that you say that the sentence shows social value?

Student : because the sentence shows compassion and sympathy for the Poor by giving food and fruits. (CL.VII / GR.I / 164)

Teacher : Well, then what does social value relate to? teach about what?

Student : Please help. Here we should want to share to ease the burden on others. (CL.XII/GR.I/165)

Teacher : Yes. What does social value mean please help?

Student : We have to help each other and to others who need it without strings attached.

Teacher : Yes, in this saga teaches us about good social ways with the surrounding community which we call social values. (CL.XII / GR.I / 166)

From the data above shows that there is the use of probing questions strategy in the process of learning Indonesian in class. When the teacher asks the value contained in the saga and the students' answers are not convincing, the teacher will ask again until the teacher believes that the answer is correct. The data above is a follow-up question that the teacher intentionally aims to have students provide further explanation of the previous answer. Here the teacher uses the probing process, where the teacher tries to make his students justify or at least explain more about their answers. With this strategy, the teacher trains students to be able to express arguments or logical reasons for the answers they provide. In addition, the teacher's use of this strategy can also help students with superficial or incorrect answers. This can increase the depth of discussion, thus making students motivated to think critically.
- Cognitive Domains of Teachers' Questions on the Use of Questioning Strategies in the Indonesian Language Learning Process

Based on the observations, the researcher noticed that one of the ways in which the teacher interacted was by asking questions to students. The questions asked by the teacher demands responses from students in the form of answers or statements. In giving questions, the teacher must pay attention to cognitive aspects. The cognitive aspects of the question include questions to reveal the ability to: remember, understand, apply, analyze, evaluate, create.

\section{a. Remembering Aspects}

Questions to improve the ability to remember involve remembering the material that has been previously learned or general knowledge that has been obtained throughout the life of students. In the teaching and learning process in the classroom, the researcher found that when giving questions, the teacher required students to recall information or subject matter that has been obtained in the previous learning activities. You can see the data below.

Teacher : We will continue the learning material last week. Does anyone still remember our material last week? Talk about what?

Student : Our material last week was about the seminar ma'am. (CL.IV / GR.I / 100)

The data above show that the questions given by the teacher require students to recall the subject matter that has been studied previously. This question is the most basic level of the existing levels. For more details, it can be seen in the other data below that shows the use of the strategy redirection questions by teacher to improve the ability to remember students in the learning process.

\section{b. Understanding Aspects}

The data below shows the use of prompting questions by the teacher to improve students' ability to understand material in the learning process.

Teacher : Today we will go into the Observation Report Text Material. Before you explain, do you think anyone knows what the text of the observation report is?

Student : (paused) (CL.IX / GR.I / 183)

Teacher : Good, because no one answered, I just want to know if you still remember the description text or the description paragraph? Does anyone still remember? Have you ever learned about the paragraph description?

Student : Ever mom (CL.IX / GR.I / 184)

Teacher : Then what is the paragraph description?

Student : Paragraph which contains an explanation of a matter

Student : Paragraph contains a detailed description in full. (CL.IX / GR.I / 185)

Teacher : What is the goal?

Student : an object

Student : observed object (CL.IX / GR.I / 186)

Teacher : Good ... are humans included objects? 


\author{
Student : Yes ma'am (CL.IX / GR.I / 187) \\ Teacher : Try Ani forward. Is Ani a living thing? \\ Try to describe about ani? \\ Student : Ani has a sweet black face, curly hair, \\ brown skin. (CL.IX / GR.I / 188) \\ Teacher : Good. If you can describe an object that \\ you see, then what is the text of the Observation \\ Report? \\ Student : text that contains an explanation of the \\ object being observed \\ Student : text that contains a report from \\ observations in the field (CL.IX / GR.I / 189) \\ Teacher : anyone want to add? \\ Students : written based on facts according to \\ observations. (CL.IX / GR.I / 190)
}

From the above data, it shows that the teacher asked students' understanding of the text of the observation report. However, when students were not able to answer, the teacher used guiding questions related to the material that has been studied before, that was the descriptive text. Guiding questions given by the teacher to students aims to stimulate students to provide answers that lead to the previous question that is the text of the observation report. The use of prompting questions by the teacher is to improve students' ability to understand further material. With the help of other questions, the teacher can improve students' ability to understand the material.

\section{c. Applying Aspects}

The data below shows the use of prompting questions by the teacher to improve students' ability to apply the knowledge they have in the learning process.

Teacher : Do you think there is value in the saga?

Student : There is Ma'am. (CL.XV/GR.III/403)

Teacher : What are the values contained in the saga and include with supporting sentences?

Student : Social Value. The supporting sentence "Because of pity with the Poor, there are people who sympathize with him who give mango, rice, clothes, and other fruits". (CL.XV / GR.III / 404)

Teacher : On what basis are you or the authentic proof that you say that the sentence shows social value?

Student : because the sentence shows compassion and sympathy for the Poor by providing food and fruit. (CL.XV / GR.III / 405)

Teacher : What then do social values relate to? Teach about what?

Student : Please help. Here we should want to share to ease the burden on others. (CL.XV/GR.III/406)

Teacher : What do you mean?

Student : We have to help each other and to others who need it without strings attached (CL.XV/GR.III/407).

Teacher : Yes, in this saga teaches us about good social ways with the surrounding community which we call values ...?

Student $\quad$ : Social. (CL.XV / GR.III / 408)
From the above data, it can be seen that students will be able to answer if they have certain categories. Students read the saga then determine the value contained. This shows that students have their own views that are supported by certain reasons or arguments. Through the process probing, the researcher found that the teacher was attempting to make students justify or at least explain more about their answers. With this strategy, the teacher trained students to be able to express logical arguments or reasons for the answers they provided. This can increase the depth of discussion so as to make students motivated to think critically in providing their assessment of the saga text.

- Teachers' Questioning Strategies in Indonesian Language Learning Structure

The strategy of asking questions that the teachers applied in their language learning structures in this present study refers to the discourse element by Tarigan (1987, p 32). The structure of the discourse in question is three, namely beginning / abstract, middle / orientation, and end / koda.

\section{A. Beginning}

At the beginning/ abstract in the structure of discourse is an opening part in the teaching and learning process which contains greetings and exposure, but often in the form of questions. In the structure of discourse, there are questions from the teacher to students as a marker of the opening of the learning process and continued with the presentation of learning materials. The examples of data can be seen below.

Teacher : Good morning. Today we will discuss facts and opinions. Anyone know what facts are? Try the last one, is that a fact?

Student : Something really happened (CL.I/GR.I/001)

Teacher : Good kids. Good afternoon. Today we will discuss the intrinsic elements of literary work. The literary work that we will discuss is drama. Before you continue, I want to ask first. What is meant by the intrinsic element of a literary work?

Student : Elements of the literary work itself (CL.II/GR.II/028)

Teacher : Good afternoon. Today we enter a new subject. Previously we have studied the subject of fictional texts, in the form of poetry, short stories and drama. Now we will study material about nonfiction text. Previously, did anyone know what nonfiction text is? Bajo, try to explain what nonfiction text is?

Students : are texts or essays produced in the form of real stories. (CL.III / GR.III / 042)

The data above represents the three teachers who asked questions using the strategy in the learning process under study. From the above data it can be seen that in the initial part of the discourse, each teacher starts the learning process by giving questions along with the use of greetings to open the learning process in class.

From the example above, the initial greeting sentences to open the learning process are then followed by questions before entering the core learning activities. In the process of learning together "GR I" is marked by the entry of the 
teacher accompanied by an opening greeting using the greetings "Good morning" then followed by the question "Does anyone know what fact is? Try the last one, what is the fact? "In the process of learning together" GR II "is marked by the appearance of the entry of the teacher into the classroom, then greeting "Good kids" or "Good afternoon", then followed by the question "What is meant by the intrinsic element of a literary work?". While the learning process with GR III, marked by the greeting "Good Afternoon", then followed by the question "Does anyone know what nonfiction text is? Bajo, try to explain what nonfiction text is?" The question at the beginning of learning is used by the teacher as a marker on the material to be learned and or as a benchmark to find out the extent of students' knowledge of the material that has been studied previously.

\section{B. Middle}

In the middle of the teaching and learning process, there are exchanges and transactions. An exchange, which is in the form of initiatives and in the form of an introduction, leads to a question, an answer to a question, and feedback based on the answers in the form of questions. A transaction starts with the teacher explaining the learning materials to students, then the teacher directs students to focus on learning by giving a number of questions related to the learning material.
Teacher
: Do you think there is value in the saga?
Student
: There is Ma'am
Teacher : What are the values contained in the saga and include with supporting sentences?
Student : Social Value. The supporting sentence "Because of pity with the Poor, there are people who sympathize with him who give mango, rice, clothes, and other fruits". (CL.XVII / GR.I / 133)
Teacher : Try to describe the stages of the flow! Based on the grooves that have been divided, explain one by one the flow stages?
Students : The introductory stage, the stage of conflict arising, the climax stage, the divorce stage, and the completion stage. (CL.XIV / GR.II / 403)
Teacher : What are the characteristics of each character you have mentioned? Starting from the main character to additional characters.
Student : Aulia has a kind character.
Teacher : What else besides that?
Student : Patient. (CL.XVI / GR.III / 604)

From the above data it can be seen that in the middle of the learning process, the teacher asked questions in between the learning materials. As shown in the transcript above, the submission of questions occurs when the learning process has entered the core of learning.

\section{Koda}

At the end of the teaching and learning process is the closing part of the teaching and learning activities in class. The end of learning is marked by giving questions to close learning activities. The teacher ended the class by describing a conclusion from the materials that had been learned and giving closing questions as a measure of student memory. Next, the teacher ended the class with a closing greeting from the teacher.
Teacher : Okay. Today we have learned we have learned about facts and opinions. Who can explain the difference between facts and opinions?

Student : That fact has already happened and can be proven and opinion in the form of someone's opinion.

Teacher : Yes, exactly. Can be distinguished that the facts are events that have or have happened and can be proven true. While opinions are events that have not yet occurred or contain someone's opinions. Hopefully what we learn today can be remembered and understood to be useful for your future life and most importantly so that later your exams can work on the questions. See you at the next meeting. (CL.I/GR.I/012)

Teacher : Okay, fine. Today we have discussed the intrinsic elements of literary works. Try to enumerate what are the intrinsic elements of literary works and explain them briefly?

Student : Theme, Figure and Characterization, Settings (Background), Viewpoint, Style, and Mandate.

Teacher : Yes, there are seven intrinsic elements in literature. I hope you guys will remember well. Good afternoon. (CL.II / GR.II / 036)

In the sample data above, it can be seen that the part is the final concluding part of a learning process. It is marked by questions from the teacher related to the conclusions from the learning materials. Then, after students answered the questions, the teacher provided the conclusions followed by hopes and prayers so that what has been learned is useful for the future of students.

From the above data, it is found similarities in the beginning, middle, and end of the discourse of each teacher. The similarity is seen at the beginning of learning, namely greeting students then giving questions as the beginning of the learning process. The initial question aims as an introduction to the material being studied and/ or to recall materials that have been studied previously. In the middle of the lesson, the teacher delivered questions in between the delivery of the materials or when the students doing the assignment given by the teacher. And at the end of each teacher, both of the teachers ended the conversation with a conclusion by giving questions related to the materials being studied. The teachers also offered the same prayer, hope, and leave taking as a marker that the learning process had ended.

\section{CONCLUSION}

In this study there are still some obstacles faced by the teacher participants, among other things, the first application of the questioning strategy is not very effective. This means that not all questioning strategies can be carried out every meeting. Often teachers only apply one or two questioning strategies in one meeting. Therefore, in order to achieve effective learning objectives, teachers should use strategies to ask questions well in the learning process that includes redirection questions, prompting questions, and probing questions. 
The second obstacle is that it is less effective in making questions that lead to an increase in students' thinking abilities, including expressions for making questions to be understood by students, directing and conditioning students, who do not understand the materials, to pay attention to the teacher's questions, and avoiding simultaneous answers to easy questions. Teachers can repeat their questions for disciplining students and stimulating students to be more active, especially groups of slow learners. Therefore, to improve students' thinking abilities, teachers should provide Bloom Taxonomy cognitive questions, which include questions to reveal the ability to remember, understand, apply, analyze, evaluate, and create.

\section{REFERENCES}

Anderson,O.W. \& Krathwohl, D.R. (2001). A taxonomy for learning, teaching, and assessing. New York: Logman.

Arikunto, S. (2002). Prosedur penelitian suatu pendekatan praktik. Jakarta: Rineka Cipta.

Edmondson, W. (1989). Spoken discourse. A model for analysis. Singapura: Longman.

Ghony, M.D. \& Almanshur, F. (2012). Metodologi penelitian kualitatif. Yogyakarta: Ar-Ruzz Media.

Hasibuan, J.J. \& Moedjiono. (2012). Proses belajar mengajar. Bandung: PT. Remaja Rosdakarya.

Hasibuan, J.J., et.al. (1988). Proses belajar mengajar keterampilan dasar pengajaran mikro. Bandung: CV. Remadja Karya.
Hunkins, F.P. (1987). Student as key questioners. In Wilen, W.W. (Ed.), Questions, questioning techniques and effective teaching. Washington, D.C: National Education Asociation.

Jacobsen, A.D., Eggen, P. \& Kauchak, D. (1989). Methods for teaching. A skills approach. Columbus: Merrill Publising Company.

Jacobsen, A.D., Eggen, P. \& Kauchak, D. (2009). Methods for teaching. Metode-metode pengajaran meningkatkan belajar siswa TK-SMA. In Achmad Fawaid \& Khoirul Anan (Ed.). Boston: Pearson Merrill Prentice Hall.

Lang, H.R. \& Evans, D.N. (2006). Models, strategies, and methods for efective teaching. USA: Pearson.

Majid, Abdul. (2013). Strategi pembelajaran. Bandung: PT. Remaja Rosdakarya

Moleong, Lexy J. (2004). Metodologi penelitian kualitatif. Bandung: PT Remaja Rosdakarya.

Moreillon, J. (2007). Collaborative strategies for teaching reading comprehension: maximizing your impact. Chicago: American Library Association

Mulyana, Aina. (2012). Kemampuan bertanya pada siswa. Dalam http://ainamulyana.blogspot.com/2012/02/kemampuan-bertanyapadasiswa.html [download 26 November 2016]

Sinclair, J. \& Coulthard, M. (1975). Towards an analysis of discourse. London: Oxford University Press.

Sudaryanto. (2001). Metode dan aneka teknis analisis bahasa. Yogyakarta: Duta Wacana University Press.

Tarigan, H.G. (1987). Pengajaran wacana. Bandung: Angkasa

Uno, H.B. (2006). Orientasi baru dalam psikologi pembelajaran. Jakarta: Bumi Aksara.

Zamzani. (2014). Pengembangan berpikir melalui pembelajaran bahasa. In Sayuti, A.S. (Ed.). Bahasa, sastra, dan seni. sebagai jalan peradapan bangsa. Yogyakarta: UNY Press. 